\title{
KULEUVEN
}

\section{Stakeholders in Universities and Colleges in Flanders}

The final publication is available at http://www.ingentaconnect.com/content/bpl/ejed/2000/00000035/00000004

DE WIT, K. \& J. C. VERHOEVEN (2000) "Stakeholders in universities and colleges in Flanders." European Journal of Education 35 (4) pp. 421-437. 



\section{Stakeholders in Universities and Colleges in Flanders}

\section{Kurt De Wit \& Jef C. Verhoeven}

\section{Introduction}

The participation of 'stakeholders' in the internal governance of universities and colleges (hogescholen) in Flanders has a long tradition. Universities have had a democratic governance structure for some 30 years now, with a representation of both university staff and stakeholders. A similar structure developed in the college sector. Therefore, when analysing changes in Flanders related to the 'stakeholder society' over the last decade, it is not so much the issue of new stakeholders that is central, but the relative importance of each group of stakeholders in university and college policy making processes.

The notion of 'stakeholder society' points at two developments with regard to the participation of 'external actors' in higher education systems (see the Editorial). First, it indicates a shift in the role assigned to these representatives of 'external society'. Second, it implies increasing responsibility on the part of higher education to account to the general public for its actions. In Flanders, these developments also seem to have taken place.

In the last ten years, the Flemish government has increasingly stressed the importance of higher education's openness to society. From its point of view, a maximum amount of autonomy must be granted to each university and college in order to make them strong enough to take part in international competition (Heffen, Verhoeven \& De Wit, 1999). As a counterpart, each institution must accept government control of the quality of its courses (Verhoeven \& De Wit, 2001). This has led to the obligation for higher education to set up a quality assurance system with external reviews and controlled by the government. Responsiveness to society has thus become a key element in assessing the quality of higher education.

But does this mean that the role of (external) stakeholders in higher education is really becoming more important? Or is the greater attention given to the responsiveness of higher education mainly rhetorical instead of an impulse for actual changes? To answer these 
questions, this article will present some results of the Flemish case studies carried out in the framework of the TSER-HEINE research project ${ }^{1}$. We shall describe how the participation of external stakeholders has grown historically for both the university and the college sector. Then we shall turn to the current situation as it is laid down in Flemish law and in the regulations of the universities and colleges themselves. Finally, we shall present four case studies, two universities and two colleges, and the way stakeholders participate in their governance and the reasons for actively involving them or not. We shall begin by outlining the theoretical perspective that guided the case studies.

\section{Theoretical Perspective: Neo-institutionalism and the Resource Dependency Theory}

The focus on the pressure on higher education to become more responsive and accountable and the changing role of external stakeholders requires a theoretical perspective for the analysis of the case studies that takes both into account. The theoretical framework developed in the TSER-HEINE project (Gornitzka, 1999) serves this purpose by combining elements of the neo-institutional theory and resource dependency theory.

Starting from an open systems perspective, i.e. the acknowledgement that an organisation has to interact with its environment for its survival, the question is what kind of interaction should be the major focus of attention. The resource dependency theory argues that the need for an organisation to be open to its environment is due to its dependence on that environment to obtain critical resources. In higher education, these resources can be government funding, staff, and students. To guarantee the flow of resources, an organisation (in our case, a university or college) will react to changes in its environment that affect this flow. In this, 'reaction' does not necessarily mean passive adaptation, but rather a (strategic) choice to cope with external pressure.

The neo-institutional perspective offers a different view on the interaction between organisation and environment. It states that the structure of organisations reflects norms and beliefs about social reality that are taken for granted. External pressure stems from the institutional environment of the organisation (Scott, 1987) which consists of the rules, expectations, and understandings shared by the members of a society. These include conceptions of which organisational structures and which organisational behaviour 'fit best'. The organisation will usually (and at least partially) have to conform to this institutional environment. As a consequence, the degree of success of a 
policy directed at organisational change also depends on the degree of institutionalisation of this policy (Tolbert \& Zucker, 1983). Or viewed the other way round, the success of an organisation depends, amongst other things, on its legitimacy, derived from taking on externally legitimised structures. This implies that organisational change does not have to involve 'real' adaptations, as long as it complies in one way or another with the change in the environment. By implementing changes in a ritualistic fashion, organisations achieve stability, despite the volatile pressures from 'outside'. This 'outside' of the organisation must be understood correctly. Although the norms and beliefs are taken to be in the environment, they are actually internalised by the individuals who form the organisational 'population'. These cultural, interpretative schemes will therefore not only influence the behaviour of these individuals, but will also be strengthened or changed by it.

But what receives little attention in institutional theory is the 'inside' of organisations, i.e. issues of power and interests of actors within organisations. Here, we must turn again to the resource dependency theory which emphasises the importance of sub-units in organisations and their role in organisational change processes. Each sub-unit will try to improve its situation by trying to manipulate the 'subjective' resource dependence, i.e. the definition of which resources are important for the organisation. The picture of the organisation becomes one of a complex social system that is not managed from one central point. Instead it can be regarded as an arena in which organisational groups exercise power against each other and try to influence each other and the leadership. Different actors compete to advance their values and interests and the means they find important (compare Mintzberg, 1983, Clegg, 1990).

The resource dependency theory tends to see power as the consequence of a number of causal mechanisms. It is often related to the division of labour (Pfeffer, 1981). But power can also be seen as a property of relations. The power struggle within an organisation takes place in complex and continuously changing patterns of interaction, governed by rules that are not fixed (Clegg, 1990). The actors try to exploit these rules to their own advantage. Subsequently, the division of labour can also be seen as a consequence of the underlying power relations.

Organisational action takes place in complex and contingent circumstances (Devos, 1995). Unforeseen external actors can play a role in the interaction field, external actors can have an influence on the power of the actors in the organisation, etc. According to Gornitzka (1999, p. 8), '[T]he underlying model is one of influence and countervailing 
power: the greater the power of external stakeholders the greater the environmental determinism, whereas greater organisational power suggests greater capacity for organisational choice'.

The implications of this theoretical framework for our study of external stakeholders' involvement in the governance structure of and change processes within universities and colleges are the following. First, the way these organisations respond to the expectations from their environment cannot be understood if one does not take into account the factors that are internal to the organisation. This means we have to pay attention not only to power distributions and power relationships, but also to prevailing values, routines and traditions. In the field of higher education, we must be aware of certain characteristics of the universities and colleges that make them 'hard to move' (Gornitzka, 1999, p. 11). For instance, higher education establishments $Đ$ in Flanders, more especially the universities $Ð$ are what Mintzberg (1979) has termed 'professional organisations'. The core of the organisation is at the bottom, i.e. the academic staff members. Implementing change throughout the organisation is therefore not straightforward. Furthermore, universities and colleges are, to a large extent, structurally differentiated. Faculties or even departments are quite independent from each other in many respects. Their identities and features can differ considerably.

The theoretical framework also indicates that the interplay between these internal factors and the external environment must be recognised. Sub-units can be fairly powerful, depending on their ability to receive external support or external legitimisation. For a higher education establishment as a whole, too, it can make a difference whether it is evaluated by outsiders or not, has to compete with other organisations or not, etc.

This theoretical perspective has guided the case study research and the analysis of the cases. In the following section, we shall begin by presenting the two case studies of universities, preceded by a brief outline of the historical background of external stakeholders' involvement in university educational affairs. Then, we shall do the same for the two case studies of colleges.

\section{Universities in Flanders: the reign of academic freedom The Ivory Tower Criticised}


The current involvement of external stakeholders in the internal governance structure of the Flemish universities has its roots in the student unrest in Belgium in the second half of the 1960s. Initially, the student agitations focused on an entirely different matter: the presence of the French-speaking section of the Catholic University of Leuven in the Dutch-speaking region of Flanders. The Catholic University of Leuven was a bilingual university where lectures have been given in both Dutch and French since the 1930s. Its governance structure has been divided into a Dutch-speaking and a French-speaking part since 1962. When the 1963 Act delineated linguistic areas within Belgium (Dutch in Flanders, French and some German in the Walloon region, and both Dutch and French in Brussels), the Université Catholique de Louvain remained a disturbing symbol of French-speaking presence in Flanders. On the basis of the 'language of the territory = language of instruction' principle, the question arose whether the Frenchspeaking section should be moved to Walloon. In 1966, the Belgian episcopacy declared unilaterally that this was impossible. This authoritarian decision caused a mass protest, not only among Flemish students, but also among the professors and the Flemish, mainly Catholic, press and social organisations. Hence, general Flemish issues became entangled with anticlerical and anti-authoritarian demands.

When, in January 1968, the academic government of the French-speaking section of the Catholic University of Leuven decided not only to stay in Leuven, but also to expand the university, Flemish students and professors held a four-week strike. The demands of the students did not only concern the Flemish character of the university, but also a 'democratic Flemish university' (until then, only professors participated in the internal management of the university, as in all universities in Belgium).

Unable to settle the conflict, the Belgian government was obliged to resign. The new coalition government began by providing a solution to the Flemish- 
Walloon problem, which was considered more important than university reform. Within the framework of university expansion, it made money available to move the French-speaking section of the Catholic University of Leuven to Wallonia and to divide the Free University of Brussels (ULB) in the same manner as the Catholic University of Leuven. As from October 1968, the French-speaking and Dutch-speaking sections of the Catholic University of Leuven began to work separately.

When the linguistic contention abated, the issue of 'joint-management' became more prominent again. On 30 June 1968, the government called a 'Conference on University Reform' in which representatives of academic, economic and social bodies, professors, assistants, and technicians would participate. It was to advise the government on necessary reforms in the public universities.

Meanwhile, at the Free University of Brussels, a student revolt broke out in May 1968 under the influence of similar events in Paris. University buildings were occupied by the students, free meetings were organised, etc. In Brussels, as in Paris, democratisation was ostensibly the objective. The demand for the division of the university into two autonomous linguistic sections, French and Dutch, came later. The board of directors said it was ready to discuss all the agitators' demands. As early as 4 July 1968 a reform committee was established by the board of directors, and already on 20 November 1968 a temporary board was installed with seven elected professors and six deans, one work-leader, five assistants, seven students, two representatives of the administrative and clerical staff and eight coopted representatives of social, political and economic bodies from outside the university.

A restructuring commission was created at the Flemish section of the Catholic University of Leuven in September 1968, at first without success. Only after new protests by the students in November and December 1969 did new regulations enter into force in 1970, based on internal democracy, but with a predominance of professors. Here too, the government did not exert any influence. 
Action in the public universities and the colleges followed, but it was not as passionate. The Conference on University Reform could only agree that the board of directors of each university should have a democratic composition. The public universities which, unlike the private universities, could not choose their own mode of government, had to wait until the Act of March 1971 before a certain degree of joint-management was introduced. In this Act, the democratisation of the board of directors was interpreted as meaning that the four sectors of the university, i.e. academic staff, assistants, administrative and technical personnel, and students, should each have a voice (although not an equal voice) in university affairs and that decisions by the boards should be made public. Academic staff was more largely represented than the other groups because of its experience and the continuity of its presence in the university. The same idea appeared in the Royal Decree in dealing with the organisation of the faculties, which continued to be 'faculties with chairs' despite the many proposals for further departmentalisation. It was also decided that henceforth the universities should not be allowed to be 'ivory towers', but should be 'open to the needs of society'. These needs were to be met by the representation on the Boards of Directors of the municipal and provincial governments and the social and economic organisations. In this, the ministers followed the example of the private universities, where this pattern had already been observed. This was not only a new situation for the universities, but also for the trade unions, which, until the crisis of 1968, had never taken much interest in the universities. As from 1971, this changed and the trade unions began intervening in the universities on behalf of the assistants and the academic staff.

\section{Democratic Governance: legislation and university regulations}

The monopoly of the professors, who used to govern the faculties collegially, has disappeared from all governing bodies of the universities since 1971. For the public universities, this was determined by the Act of 24 March 1971; the private universities changed their regulations in the years before that. However, both the legislation and the universities' regulations left the main authority in the hands of those members of the university who were likely to work there the longest. This was not meant to ignore the importance of the other groups, but to guarantee that the group that had traditionally determined the university's goals would be able to maintain those goals even if other aims had to be included. The current composition of the governing bodies of the universities is still based on the principles established in 1971. The same groups are represented in the governing bodies, in similar mutual ratios, although the actual numbers have changed. 
In principle, each university is responsible for its internal organisation. For the public universities, however, this is only partially true. The Special Decree of 26 June 1991 transferred the organising authority from the Flemish Government to the public universities themselves. Before, they depended on the Minister of Education for many important decisions, such as final decisions regarding appointments and the creation of new chairs. Even today, their organisational framework is established by decree. In contrast, the private universities had and have great autonomy. Therefore, their organisational structure differs. Below, the governance structure of the Catholic University of Leuven (KUL) is presented as an example of a private university. We also outline the situation in the public universities, as defined by the Special Decree and further established by the universities themselves. In each case, we study the competence and composition of the bodies in which stakeholders are involved.

\section{The Governance Structure of the Catholic University of Leuven (KUL) and the Public}

\section{Universities}

Starting with the central level of the KUL, stakeholders can be found in the Board of Directors and in the Academic Council. The Board of Directors administers the university and represents it before third parties. It consists of the vice-chancellor, the general manager, the vice-chancellor of the Kortrijk campus, the deputy vicechancellors, the coordinators (for education, research, and student policy) and 'other members', including at least four members who are not university staff.

The Academic Council determines and coordinates the policy on education, scientific research, and scientific services. Its composition is similar to that of the Board of Directors, but it does not include the category 'other members'. It comprises the deans of the faculties, the academic ombudsman, and representatives of the students (four) and the auxiliary academic staff (three).

At the central level of the public universities, stakeholders are involved in the Board of Directors and the Administrative Board. The Board of Directors is the most important administrative body and is responsible for matters comparable with those of the Board of Directors of the KUL. It consists of 33 voting members: the vice-chancellor, the deputy vice-chancellor, twelve professors, two assistants, four students, three representatives of the employers' organisations and three of the trade unions, and four representatives appointed by the Flemish Parliament. 
The Administrative Board consists of the vice-chancellor, the deputy vice-chancellor and elected representatives of the different groups within the Board of Directors (two representatives of the professors and one representative for each other group). Amongst other things, it prepares and executes the decisions of the Board of Directors. Moreover, it has residual competence in all matters that are not explicitly attributed to the Board of Directors.

The Decree on Universities (12 June 1991) guarantees the participation of students in decision-making. Every university must establish a Council of Students if the students are not already represented in the highest body of the university that discusses matters that directly concern them.

Finally, in accordance with national labour legislation, private universities have a Work Council (minimum 100 persons employed) and/or a Committee for Prevention and Protection on the Workplace (minimum 50 persons employed), just like all other companies in Belgium.

Turning to the sub-unit level, and still taking KUL as an example, there is a Faculty Council in each faculty, composed of the professors and representatives of the assistants and the students. The faculties are responsible for planning, organising and coordinating education and for coordinating and stimulating the departments. Every faculty of the KUL has one or more departments that are responsible for the organisation and coordination of scientific research and scientific services. At this level, there is a departmental council whose composition is similar to that of the faculty council, but which is restricted to the members of the department.

The Special Decree (1991) grants the Board of Directors of the public universities the power to establish faculties, departments, subject groups, and other bodies considered necessary for the university to fulfil its mission. Generally speaking, the coordination of the provision of education and scientific research is situated at the level of the faculties. 
The faculty councils consist of all the professors and representatives of the assistants, the technical and administrative staff, and students. For each discipline or group of disciplines, there are departments, on a faculty or inter-faculty basis. Since the abolition of the principle of faculties constituted by chairs, the departments are the smallest management units that are responsible for education. They also have a coordinating role with regard to scientific research and service.

Finally, we must mention two mainly advisory bodies that were established in all the universities, although they are not obliged to do so by law: the educational council at the central level that advises the central governing bodies on educational matters, and the education committees that advise the faculty council. Students are represented in both, although their number and share differ from one university to another.

\section{Involvement of Stakeholders in Flemish Universities}

In public universities, professors are no longer in a predominant position; in private universities they are still a majority in the decision-making bodies. But their ability to influence decision-making does not depend solely on their number and share. The actual (rather than formally possible) involvement of the stakeholders is important too.

In this section, we shall analyse some results of the TSER-HEINE research project, relating to socio-economic stakeholders in governing bodies for education in two Flemish universities. The first case is a large private university, the second a large public university. We shall discuss the ideas of the central governors about the relationship with the economy and socioeconomic stakeholders, the way these stakeholders are involved in central decision-making, and the situation in four faculties of each university. 


\section{University Case A}

The dominant idea at the central university level about the relationship with the economy is that the university must be reserved about demands coming from the socio-economic stakeholders. Tendencies in society should not be ignored, but the university must transform them into a university project. The goal of university education is to provide people with general, broad education that can remain valuable for the rest of their life. This project should not be linked to the hype of the moment and the often specialist demands of the economy.

Notwithstanding the stress on the specific identity and the proper goals of university education, university A experiences a growing impact of the economic rationality on university action and thinking. The main reason is the growing competition in attracting external financial resources on the national and international research markets.

Furthermore, the university's environment exerts some pressure in indirect ways. The academic staff has contacts in the professional world or works only part-time at the university. An educational framework of reference must be established for each course in which attention must be given to the labour market of graduates. A similar concern is found in the reviews.

Direct involvement of external stakeholders is only possible on a limited number of occasions. External stakeholders are represented on the Board of Directors, but this board has no direct role in the educational policy. An alumnus can be and often is taken in as a deputy member in the evaluation commissions and the education committees. Finally, external stakeholders are very present in the structure of continuing education of university A, i.e. they make up half the members of the steering committees in this area (intermediate bodies between supply and demand) and they are represented in the continuing education council, an advisory body at the central university level.

Two problems arise here with regard to the involvement of the external stakeholders. First, it often happens that internal university affairs are discussed in the council. This can be considered a waste of time for the external members. Second, and more important, questions raised by the external members often cannot be answered by the representatives of the university nor be addressed in the time frame that is considered appropriate by the external members. 
In short, at the central level of university A it is believed that external stakeholders do not have much influence, even $Ð$ and perhaps especially $Đ$ when they are formally represented. This picture is confirmed in the faculties. In the four faculties we examined (engineering, economics, law, and pharmaceutical sciences) external stakeholders have an indirect influence via their contacts with individual academic staff members. These contacts are in general not organised. However, in the Faculty of Pharmaceutical Sciences the professional organisations and the alumni association are active and important. The Faculty of Engineering has an advisory council which consists of faculty members and industrialists, and, at the department level, advisory councils with alumni. But these councils seem to be more of a way of fostering a good relationship with important industrialists.

According to the faculty members, the reason for this little involvement of external stakeholders in faculty affairs is that economic demands change too rapidly, are too fashion-oriented, and therefore run counter to the mission of university education, i.e. offering more permanent insights.

\section{University Case B}

Generally speaking, the central level of university B is in favour of keeping contact with the social environment, including the economic environment. It incites the faculties to involve alumni more closely in educational reforms because their feedback about the education and other university tasks is essential for quality maintenance and improvement and because their labour market position is a good way of measuring the socio-economic appreciation of the courses of the university. But the decentralised organisation model is stressed even more than in case A. The involvement of external stakeholders is believed to be a faculty level responsibility, and, in practice, it is realised at that level. There is little external pressure on the central university level (and this is certainly true for pressure from socio-economic actors) because the central level is not strongly involved in the field of education and because socio-economic actors do not have many possibilities to exert direct pressure on the university. They are only present in one central body (the Board of Directors). Moreover, we must remember that the central level was not very relevant in the old structure of the public universities (before the Special Decree of 1991). Because of the strong decentralisation, the situation with regard to involving stakeholders differs considerably from faculty to faculty. But a picture emerges that is very similar to case A. 
First and foremost, individual contacts between professors on the one hand, and business representatives or alumni on the other, are the most important channel of influence of external stakeholders in all four faculties examined (engineering, economics, medicine, arts and philosophy). The Faculty of Economics even tries to stimulate these informal contacts rather than strengthen the formal ones. The Faculty of Engineering is the only one to have a clear formal representation of external stakeholders. It has an advisory council with an equal representation of academics and industrialists to discuss the long term options for the teaching programmes. There is also a (small) deliberation forum that helps to define the knowledge to be offered to the students.

Again, this absence of formal representation is explained by the contradiction between the economy's demand for practical, transitory knowledge and the aim of university education of providing a broad and general knowledge base. Yet the interviewees believe that the involvement of external stakeholders in curricular reforms is increasing in university B. In accordance with the central guidelines, alumni and business representatives are asked more often to participate in educational reforms. Also, guest professors from outside the academic world and practical training assistants are appointed more frequently. The reviews that assess the relevance of programmes for the occupational field and whose members can be socio-economic stakeholders have an increasing impact. They are seen as an important catalyst for changes, especially through the self-reflection they imply. Finally, students can evaluate education on a structural and regular basis within the framework of the quality control structure.

\section{Colleges in Flanders: A clear orientation on the vocational sector}

Democratisation in the Wake of University Reform

In the wake of the changes in the governance structures of the universities the position of stakeholders in the colleges (hogescholen) also changed. The changes took place more smoothly than in the universities.

At the national level, stakeholders obtained a place in the 'high councils' for the different parts of college education through the Act of 7 July 1970 on the general structure of higher education. These councils advised the Minister of Education on their own initiative or on the Minister's request. Their members were representatives of the organising authorities of the colleges and of the teachers and of the students and the social and economic sector. 
At the local level, the Royal Decree of 1 August 1977 determined that the Board of Directors of the public colleges should be composed not only of the director and his adjunct and representatives of the teachers and the staff, but also of two representatives of the students and four persons (nominated by the other members of the Board) appointed by the Minister of Education. The latter were nominated on the basis of their knowledge of the fields of study offered by the college. Although the private colleges were not obliged to follow these regulations, it became a custom in these colleges to also have external stakeholders on the Board. The same Royal Decree also established a 'Social Council' in each college. Besides the director and his adjunct, five student representatives were elected among and by the students, as well as one representative of the staff for each union present in the college. This council could advise the Board of Directors.

In the following years, the principle of a representation of stakeholders was given several new legal bases (the Special Decree of 19 December 1988, and the Decree of 23 October 1991 that organised the participation of parents and other stakeholders in private schools), but the principles did not greatly change. But one important difference between public and private colleges should be stressed. Whereas the stakeholders in public schools could participate in decision-making, in private colleges, the legal rights of the stakeholders in participation councils were confined to taking part in the deliberations. Yet the stakeholders in the Board of Directors in both public and private colleges had equal decision-making rights.

\section{Legislation on Democratic Governance in Colleges}

The College Decree of 13 July 1994 defines the current legal position of the colleges and prescribes their administrative organisation and the position of stakeholders in the different councils. As before, the Decree distinguishes between public colleges and private colleges.

A public college is governed by a Board of Directors, consisting of the representatives of the different categories of the personnel elected for four years by the personnel, representatives of the students, elected for two years by the students, and the representatives of the organising body or the representatives of the socio-economic and cultural sectors (also for a four-year term). The Director advises this council. The Board of Directors determines the regulations concerning administration, examinations, and discipline, establishes the budget, appoints the personnel, establishes the framework for the organisation and the coordination of the tasks of the institution, etc. The directorate 
consists of the chairman of the Board of Directors, the director, and three representatives of the personnel appointed for four years by the Board of Directors. The directorate is responsible for the daily administration and for the preparation, announcement, and execution of the decisions of the Board of Directors.

In private colleges, the Board of Directors co-opts its members independently, but most boards co-opt stakeholders (though not always students) as well. The College Decree, like the University Decree, mainly confers advisory tasks to the private colleges' administrative bodies. One of these is the academic council that consists of elected representatives of the Board of Directors of the college (with a term of four years), of the personnel (also four years), and of the students (two years). It is entitled to receive information from the Board of Directors concerning all educational matters. It advises the Board of Directors on the education-related aspects of matters such as the research policy. It also has `competence of consultation', i.e. the power to take decisions regarding educational aspects of matters such as the financial policy, the policy concerning education and examinations, and the organisation of study guidance, on condition that the decision is taken by consensus. If there is no consensus, the Board of Directors will take the decision.

Each college, both public and private, must also establish a council of students, consisting of at least 8 and at most 16 elected students. The Board of Directors must consult the council of students before taking a decision on all matters that have direct relevance for the students (e.g. regulations concerning education and examinations and the evaluation of the teaching staff). The council of students may also take advisory initiatives.

Concerning conditions of employment, each college and each of its departments have a negotiation committee to regulate the relations between the employer and the staff unions. At the level of the college, the negotiation committee consists of the representatives of the Board of Directors and staff representatives.

Each college is divided into departments. For each department in a public college, there is a departmental council composed of the same parties as the 
Board of Directors (with the same terms, but with a different proportional composition). This council elects the head of the department, who serves as chairman of the council for a four-year term. The departmental council is responsible for the establishment of educational programmes, examinations, research programmes, the recruitment of temporary personnel and the nomination of permanent personnel, the internal organisation of the department, and the annual budget proposals.

At private colleges, a departmental council must be established for each department. It consists of the head of the department (appointed by the Board of Directors of the college), who is also the chairman of the council, elected representatives of the teaching staff (half the council), elected representatives of the students (a quarter of the council), and representatives of the socio-economic and cultural sectors (a quarter of the council), coopted by the head and the teachers and student representatives. This council has the right of information for all matters concerning the department and may advise on a range of departmental matters when asked by the Board of Directors of the college or on its own initiative. In other words, the departmental council is an advisory body in private colleges, whereas in public colleges it takes part in the decision making. At both public and private colleges, the departmental negotiation committee consists of representatives of the department council and of the personnel. The latter are elected among the teacher candidates proposed by the unions.

Stakeholders do not only influence the college governance at the local level, but also have a say in the design of the college curricula at the level of the Flemish Community. The Decree stipulates that colleges should design the course profiles in accordance with the vocational profiles developed by the Flemish Education Council (VLOR). The VLOR is both a body that advises the Minister of Education and a forum for consultation and debate concerning all educational matters. It consists of representatives of the social and economic organisations, the educational trade unions, the governing bodies, and parents organisations. The VLOR organises consultations 
between the educational field, the Social and Economic Council of Flanders (SERV) and the Department of Educational Development of the Education Department of the Ministry of the Flemish Community (DVO) about the vocational and course profiles.

\section{Involvement of Stakeholders in Flemish Colleges}

Just like in universities, stakeholders have attained a clear position in colleges, although there are some positional differences between stakeholders in public and private colleges as far as their legal rights in the participation in decision-making are concerned. Yet, in both public and in private colleges they may play an important role in decision-making, as will be seen below.

But before discussing the position of the social and economic stakeholders in two colleges, we shall give a short overview of results of a survey of a representative sample of the members of the Board of Directors, the departmental councils, and other participative councils in the Flemish colleges (Devos, Verhoeven, Maes \& Vanpee, 2000). They were asked about the importance of the role played by the social and economic stakeholders in the Board of Directors and in the departmental council.

The item `External stakeholders play an important role in the decision making of the Board of Directors' could be rated by the members of the different Boards of Directors ( $\mathrm{N}$ $=67$ ) from 1 to 5 , the latter being the most positive. The mean score was 3.76, which is higher than the answers on a similar item concerning the contribution of the representatives of the personnel on the Board (score $=3.45$ ) and of student representatives (mainly in public colleges) (score $=2.65$ ). If the external stakeholders seem to have some influence on the Boards, this is less so in the departmental councils ( $\mathrm{N}$ $=384$ ). Their score here is 3.07, which is lower than that of student representatives (3.16) and of staff representatives (3.85) (Devos et al., 2000, pp. 349, 362).

Who are these stakeholders? Although they are members of higher education boards, not all obtained a higher education degree: $4 \%$ only attended secondary school, whereas $44 \%$ obtained a college degree, and $52 \%$ a university degree. $13 \%$ were self-employed, $8 \%$ were clerks or officials, $14 \%$ were teachers, $45 \%$ were executives, and $20 \%$ were retired.

To have a more detailed view of the involvement of external stakeholders in the educational governing bodies of colleges, we shall now turn to two TSER-HEINE case 
studies of colleges in Flanders. The first concerns a private college that only offers courses in economics; the second is a large, general college in the public sector.

\section{College Case C}

The main objective of College $\mathrm{C}$ is to prepare students for a successful professional career. The courses offered are both business-oriented and of an academic level. The curriculum implies close cooperation between the college, the government, the business sector and the non-profit sector. By providing a full evening programme alongside a day programme, the college wants to stress the business orientation of its programmes and meet the growing demand for in-service training. In order to adapt the curriculum to the demands of the labour market, it tries to continuously update and revise its curricula. The interviewees stress that this attitude and the consequent functioning and organisation (practice-oriented education, attuned to external signals) are highly valued by the companies and organisations which recruit its graduates. In addition to the business aspect, the training concept stresses a critical, problem-solving method, the self-activity of the student, and the development of an international vision (by means of multilingual communication).

In college $\mathrm{C}$, stakeholders play an important role in several councils. The members of the general assembly represent the cultural, social, economic and academic sectors. Some members act as the Board of Directors, though most are not stakeholders, but members of the management of the college. This Board is responsible for the course programme, the formal educational structure, the study load, exam regulations, and quality assessment. The academic council is composed of $3 / 8$ representatives of the general assembly, $3 / 8$ representatives of the teaching staff, and 1/4 representatives of the students. The academic council is the highest academic body. It has the right on information about any subject related to the college and has advisory and deliberation authority. In other words, it has academic responsibility for the college's educational policy.

The resonance councils are also important. Their members (between 4 and 11) are not academic or scientific staff of the college. They are representatives of companies or other organisations operating in the labour sectors of the future graduates of the college. They may also be academics whose professional activities are in the speciality of the graduation fields. The resonance councils meet at least every two years to discuss the relevant targets, the content, and the structure of the specialist options in the second cycle, and can advise the academic council on these matters. 
The quality assurance system of college $\mathrm{C}$ is also strongly influenced by the economic world. A major revision of the curriculum was carried out within the framework of a special programme launched in 1994. As a consequence, the business orientation of the curriculum was strengthened and new courses were introduced. In the following years, an external audit granted the college several ISO-9001 certificates to several parts of the organisation.

More than the universities, college $\mathrm{C}$ is interested in hiring guest professors who work in the business sector, in the civil service, and in the non-profit sector. They mainly teach in the second cycle, where they provide close contact between students, teachers, and the professional practice. At present, about 1/3 of all professors of the college are guest professors. But in a number of fields there is no direct involvement of external participants, but rather close practical cooperation between the college and the business sector (e.g. in projects offered to the students by companies).

This college is very ready to deal with external pressure from the economic world. It even tries to act as a company (using the same quality standards, applying management principles, etc.) in order to give the students the experience of how a company really works.

\section{College Case D}

College D differs from college $\mathrm{C}$ in many respects. It is the result of a merger of different smaller colleges and does not only provide two-cycle training (courses lasting four years), but also one-cycle training (three years). As a result of this more complex situation, different views and practices exist in college D regarding the involvement of external stakeholders.

Although the Board of Directors is partly composed of stakeholders from the socioeconomic and cultural sector, there is little direct interference of these sectors in the central administration of the college. But the College Decree of 1994 introduced a new mission: the college should not only provide education, but should also render services to society and carry out research. Moreover, this Decree made the college aware of its relationship with the economy, by stating that the relationship with the alumni and the business sector must be supported within the framework of quality assurance. In college D, this has led to the appointment of a quality coordinator and the definition of a number of quality priorities. 
One of these quality priorities is the analysis and formation of the course programmes in function of the course profiles and the vocational profiles (see above). This is seen as a way to evaluate the relevance of its goals in the light of societal developments. Yet college D does not wish to be totally controlled by external stakeholders either. Hence, the departments must take into account the ideas of the business sector and the alumni, but they do not have to accept their proposals blindly: practical training suggested by a company or organisation does not have to be accepted by the department if it does not fit into ongoing or planned projects.

But the general attitude to the economy is favourable. This is seen in the ways in which the departments are in contact with the economy. All courses offer students practical training, albeit in different forms and with different names, which is established in cooperation with companies (sometimes also universities). In some cases the training takes place in the company, in others it takes place in the college at a company's request and with the support of that company. The companies are not only involved in the organisation of the practical training, but also in the evaluation of the students. Professional organisations play an important role for some courses (e.g. in the construction sector $Đ$ real estate).

Guest professors are appointed especially for courses in which it is more difficult to have practical training or involvement of professional organisations. This is said to be important to update the courses. The guest professors are also involved in the evaluation of the students.

Of the members of the department councils, 1/3 are co-opted among socio-economic stakeholders. The influence of the latter is seen as being more indirect than direct. The case studies we made of three departments (engineering, business and commerce, and health services) illustrate this. The interference of the stakeholders in these departments is confined to the technical aspects of some fields. They do not interfere in the general education.

In short, in the opinion of the interviewees of college $\mathrm{D}$, the relationship with socioeconomic actors must take the form of cooperation. Nor the college as a whole, nor any of its departments may be dominated by external factors. Yet the significance of external stakeholders for many courses is great.

\section{Different Levels of Involvement of the Stakeholders}

The central question in this article was whether or not external stakeholders have become more influential with regard to the educational activities of universities and colleges. The 
results of the four case studies show that the way in which stakeholders are involved in the higher education establishments differs between universities on the one hand and colleges on the other. The continuing divergences between these institutions, despite a trend towards convergence, has recently been confirmed for other aspects of their education activities (see Verhoeven, Vandeputte \& Vanpée, 2000).

The TSER-HEINE case studies show that universities have remained autonomous organisations where a formal representation of 'society's interests' exists, but in which decisions are still taken by the academics. The interviewees almost invariably refer to the concept of academic freedom and stress the specific mission of a university and of university education. Besides, the legislation also confirms the predominance of the academic staff in academic decision-making.

But nor is the 'outside world' absent. Many academics have contacts with business (or in some cases are in business themselves). These contacts are for the main non-organised, informal contacts. Further influences from the outside world come from the external reviews, the educational framework of reference (case A), and guest professors (especially in case B).

The influence of external stakeholders in these cases is more informal and is not decisive. Moreover, problems arise in formal councils as a result of the diverging agendas of the university members on the one hand and the external members on the other. Councils in which both parties are represented mainly seem to be a way of intensifying relationships. On rare occasions, stakeholders do play a significant role. The cases do not directly point at this, but one clear example was the branching off of the management school from university $\mathrm{B}$ as a result of the students' legal actions to dispute the unclear position of the management school in the structure of the university.

The situation in the colleges is different. They are legally obliged to take external viewpoints into account. They must draw up vocational profiles in conference with the relevant occupational fields and design the course profiles in accordance with the vocational profiles. Being more vocationally-oriented, colleges also have more formal contacts with external stakeholders than universities. First, many contacts are established within the framework of practical training, which is also an obligation for the colleges. A similar situation exists with respect to facilities for thesis projects. Furthermore, an important interface between college and stakeholders is the appointment of guest professors (a practice that is used much less in universities). In addition to the formal 
contacts, informal influences $Đ$ often resulting from the formal meetings $Đ$ are important too, although less so than in the universities.

The two case studies show that the attitude in colleges is more business-oriented than in universities and is in general more favourable to the socio-economic context. In case $\mathrm{C}$, this business orientation is stated as an explicit goal. In case D, it is stressed that being business-oriented should not mean being dominated by the business sector, although courses that prepare for a certain profession are greatly influenced by the vocational field. With this comparison, we can return to our theoretical framework. The research design of the TSER-HEINE project implied a focus on any given policy at a certain moment in time, instead of taking one policy and following it throughout its implementation. This means we cannot infer causal relations, but it does enable us to find the elements that play a role in the relationship between internal and external stakeholders in decision making processes in higher education institutions and to see the interplay between these elements.

The theoretical frame pointed at a number of such elements that could explain the position of external stakeholders in the internal policies of universities and colleges. Within the institutions, it pointed at both power relations and belief systems. Moreover, the relationship between each of these elements and the 'outside world' was seen as important, i.e. support for the power position of different groups and legitimisation for the prevailing beliefs respectively.

The power of the different groups in the governance bodies of higher education institutions reveals another pattern in universities and colleges. Seen from the academic teaching staff's standpoint, universities guarantee a more independent position than colleges. Hence, the informal side of relations overshadows the formal representation of external stakeholders in universities, whereas in colleges the prime channel of the stakeholders' influence comes from their formal position and competence. This situation is externally confirmed and strengthened by the provisions laid down in the Flemish higher education legislation. For universities, the law clearly acknowledges the more important role of the academic staff as compared to the external stakeholders. In colleges, the staff must take account of the viewpoints and demands of external stakeholders on several occasions, for instance in the case of vocational profiles.

As regards the norms and beliefs that prevail in the higher education institutions, we see a pattern that runs parallel to the organisational power distribution. In the universities, the belief in the traditional image of academic freedom is widespread among academic staff. The introduction of democratic governance structures in the 1970s apparently did not 
change this. On the contrary, it seems generally accepted $Đ$ and also by the public $Đ$ that professors should be the most important party in the university decision making processes. The staff in colleges has a much more favourable attitude towards external stakeholders. This is probably because a large part of the staff is external to the college and that colleges were originally established as a vocationally-oriented extension of secondary education. This explains why the introduction of a more open governance structure was less problematic than in the universities.

On the basis of our four case studies, we can conclude that the role of external stakeholders in Flemish higher education cannot be described homogeneously. In universities, the tradition of academic freedom remains central, both in the value system and in practice, meaning that external stakeholders have an indirect influence at the most. As far as colleges are concerned, all internal and external elements point to a greater impact of the external stakeholders than in the universities. However, independently of the internal values and structures, all higher education institutions seem to experience growing pressures from the 'outside world'.

\section{NOTE}

1 The project 'Governmental policies and programmes for strengthening the relationship between higher education and the national economy (HEINE)' is a EU-funded TSERprogramme (SOE-CT97-2018). In Flanders, it involved a study of governmental policies and programmes at the Flemish level and case studies of organisational change in four higher education institutions (see: Gornitzka \& Maassen, 2000). 


\section{REFERENCES}

CLEGG, S. R. (1990) Modern Organizations. Organization Studies in the Postmodern World (London, Sage Publications).

DEVOS, G., VERHOEVEN, J. C., MAES, S. \& VANPEE, K. (2000) De werking van de bestuurs- en medezeggenschapsorganen in de hogescholen (Leuven/Gent, KU Leuven $Ð$ Department of Sociology/Vlerick Leuven Gent Management School).

DEVOS, G. (1995) De flexibilisering van het secundair onderwijs in Vlaanderen. Een organisatie-sociologische studie van macht en institutionalisering (Leuven, Acco). GORNITZKA, AÊE . (1999) Governmental policies and organisational change in higher education, Higher Education, 38, pp. $5 \pm 31$.

GORNITZKA, AÊE \& MAASSEN, P. (2000) The economy, higher education, and European integration: an introduction, Higher Education Policy, 13.

HEFFEN, O. VAN, VERHOEVEN, J. C. \& DE WIT, K. (1999) Higher education policies and institutional response in Flanders: instrumental analysis and cultural theory, in: JONGBLOED, B., MAASSEN, P. \& NEAVE, G. (Eds) From the Eye of the Storm. Higher Education's Changing Institution (Dordrecht/ Boston, Kluwer Academic Publishing).

MINTZBERG, H. (1979) The Structuring of Organizations (Englewood Cliffs, Prentice Hall).

MINTZBERG, H. (1983) Structures in Fives: Designing Effective Organizations (Englewood Cliffs, Prentice Hall).

PFEFFER, J. (1981) Power in Organizations (Cambridge, Mass., Ballinger Publishing Company).

SCOTT, W. R. (1987) Organizations: rational, natural and open systems (London, Stanford University / Prentice Hall International).

TOLBERT, P. S. \& ZUCKER, L. G. (1983) Institutional sources of change in the formal structure of organizations: The diffusion of civil service reform, 1880 1935 , Administrative Science Quarterly, 30, pp. 22 \pm 39 . 
VERHOEVEN, J. C. \& DE WIT, K. (2001) Quality Assurance and Institutional Autonomy. Recent trends and policies in higher education in Flanders, Higher Education Policy, 2001, 1 (forthcoming).

VERHOEVEN, J. C., VANDEPUTTE, L. \& VANPEE, K. (2000) Universiteiten en hogescholen: elk hun eigen roeping? (Leuven, KU Leuven Đ Department of Sociology). 